\title{
The Corresponding Study of Constructivism Teaching Theory with English Teaching Reform
}

\author{
Ting Wu \\ Wuhan Huaxia University of Technology, Wuhan, Hubei, 430223
}

Keywords: constructivism teaching theory; teaching reform; development trend

\begin{abstract}
Nowadays, with the development of education, applying the constructivism teaching theory to practical teaching has attracted more and more attention from educators. The majority of educators have also started to actively use constructivist teaching theories in practice and guide their own teaching. This paper makes a brief introduction to constructivism, explains some characteristics of constructivism, and makes a simple analysis of its corresponding inspiration in English teaching.
\end{abstract}

\section{Introduction}

In all kinds of schools, English teaching is an important part of teaching activities, but the school's teaching model is generally behind. Especially in higher vocational schools, while undertaking the task of cultivating higher vocational talents, the English teaching format still follows the high school textbook style education, which does not improve the students' comprehensive practical ability. Constructivism makes innovations and breakthroughs in the traditional education model and proposes more advanced theories. The introduction of constructivism in higher vocational colleges and its integration with its own English education reform can effectively improve the level of English teaching and improve students' abilities. Constructivism is a new teaching theory. It plays a decisive role in international education and greatly promotes the development of international teaching reform. The proponent of constructivism theory is Piaget, who proposed this concept in the 19th century. After the educators have continued to develop and perfect, they have gradually formed a complete educational theory. In the theory of constructivism, it advocates changing the previous model of indoctrination by teachers, but advocates that learning should be student-centered, allowing students to freely construct a knowledge structure in their brains so that students can be in special situations. Active learning in the initiative to actively build the knowledge system. And appropriately develop the students' inquiry ability and cooperation ability to improve the overall quality of students [1].

\section{The Guiding Role of Constructivism Theory}

In the traditional teaching model, the teacher's main responsibility is to impart knowledge to students, so long as the students fully understand and can skillfully apply in the exam. In constructivist theory, there are different opinions. The constructivist theory advocates that in addition to imparting knowledge, teachers need to become mentors for students' learning and guide students to conduct in-depth knowledge exploration. In English teaching activities, in addition to teaching necessary grammar structures and words, teachers of higher vocational colleges also need to introduce relevant background knowledge and application environment, and strive to create an environment that adapts to the content of English learning so that students can in a specific environment, the content of learning is explored and practiced, and student performance is evaluated, as well as flash points and deficiencies. Improve students' interest and confidence in learning [1]. In modern education, students must be placed at the center of education. Especially in the more practical courses such as English teaching, students' main role is more important. Constructivism also has a guiding role for students' learning concepts and helps them establish a correct view of English learning [2]. Constructivism has changed the previous one-way 
transmission of knowledge from teachers to students, increased the interaction between students and students, students and teachers, allowing students to fully display their own subjective initiative, allowing students to establish the concept of active learning and inquiry, and improve English autonomous learning ability. In English teaching activities, as students continue to deepen their learning, grammar structures and tense voices that students need to master become more and more. If students cannot sort out in a timely manner, confusion of knowledge points will be affected, and subsequent ones will be affected. Learn. The important point of constructivist theory is to allow students to establish the cognitive structure of the system. By allowing students to conduct independent exploration of knowledge points, students can construct the structure of English learning through their own methods and have systematic knowledge of old and new knowledge. Systematic construction of knowledge points can avoid mistaken application due to confusion of knowledge, and can also correctly distinguish similar structures.

The constructivist learning theory is inherited, criticized and developed on the basis of theories of behaviorism and cognitivism that prevailed in the past. The constructivist theory points out that people cannot rely on the stimulation of the surrounding environment to acquire knowledge and information [3]. The occurrence of the cognitive process must be influenced and interacted with the internal psychological mechanism of the cognitive environment. Therefore, learners must use certain learning materials to construct their knowledge in the context of a certain context, cultural background, and learning environment with the help of teachers, study instructors, or other learners. How much learners ultimately acquire knowledge and skills is not because they memorize or memorize book content mechanically, but because of their ability to actively construct relevant knowledge based on their own experience and specific circumstances.

\section{The Enlightenment of Constructivism Teaching Theory to English Teaching}

Constructivism teaching theory has a very important meaning for modern English teaching. It breaks the traditional English teaching ideas and provides a new way of thinking for modern English teaching. It is an education model based on a new pedagogy perspective. The enlightenment of constructivist teaching theory to English teaching is mainly divided into the following aspects: In modern English teaching, English teaching has increasingly paid attention to the shift from "bilateral teaching" to "multilateral interaction". Traditional English teaching tends to focus only on the relationship between teachers and students in teaching and learning, while ignoring the cultivation of other students' abilities. The integration of constructivism into modern English teaching can be said to refer to lectures as a process in which students actively construct knowledge, and this construction process is accomplished in conjunction with others. It is a multilateral and interactive way of learning. In this way of learning, the relationship between students has also become a good cooperative relationship due to constructive reasons. Teachers and students have also become good collaborators in their studies. Modern English teaching is shifting from passive transfer learning to active constructive learning. We need to fully understand that teaching is no longer simply a passive transfer of knowledge. It is no longer the teacher who simply speaks about students. Simply listen, but it involves repeated and interactive discussions of new knowledge, including students and teachers. Teachers should pay attention to the initiative and enthusiasm of students' learning in the teaching of foreign languages. At the same time, they should give students some initiative in learning. It can be said that traditional English teaching is almost teacher-centered, and student-centered classes are rare. The most common methods of education are teachers' word-by-word explanations and quizzes, while students take notes, listen to lectures, and so on. Throughout the entire teaching process, the teacher's explanation process accounts for a large proportion, and this directly affects the enthusiasm and initiative of students' learning. The time for students to ask questions independently is reduced, and they lose their enthusiasm and initiative in foreign language learning. After sex, it is even more impossible to complete creative learning. Therefore, to change this situation, as the majority of English language education educators, it should be more reasonable to learn the latest research results of educational psychology, and apply it to their own teaching. In modern English teaching, teachers should pay special attention to the 
cultivation of students' learning environment and psychological environment. Teachers must not only complete the dissemination of their language knowledge in the process of students learning English, but also use English as an intermediary to create a good learning environment and a good psychological environment for students to help them develop their awareness and ability to learn independently. Psychologically greatly enhance their self-confidence in learning foreign languages. In the whole process of teaching, students are encouraged at all times to allow them to establish a good sense of self-selection and self-responsibility. Moreover, teachers must be careful not to impossibly impose knowledge on students and ignore their subjective consciousness. It can be said that constructivism is very much emphasizing the role of learning environment in students' foreign language learning and constructivism believes that the role of teachers should definitely not be confined to the mere provision of knowledge, but should be based on their own abilities to create a A good, relaxed learning environment that motivates active learning. It is believed that in such an environment, students' efficiency in learning a foreign language will be greatly improved. The educational function of our country is undergoing some major and unprecedented changes. The once simple method of imparting knowledge has gradually shifted to the cultivation of all-round capabilities. The focus of education has also changed from simply acquiring knowledge to cultivating students' comprehensive innovation capabilities. In the relevant documents issued by the Ministry of Education, it is clearly stated that: Colleges and universities should vigorously strengthen the quality education of students, and cultivate high-quality talents with innovative spirit, practical ability and entrepreneurial spirit. The use of constructivist teaching theory in English teaching can be said to open up entirely new areas of education. Therefore, constructivism will also play an active role in guiding English teaching in China [4].

Constructivism emphasizes the importance of learning environment for knowledge construction and meaning construction. It is believed that only in a suitable language environment and learning environment can students absorb, assimilate, adapt and update knowledge more quickly, and achieve the purpose of meaning construction. For English learners, the English classroom environment is crucial. First of all, teachers should use English to the greatest degree when teaching, not only the audio and video materials used in the classroom use English, but also require students to answer questions in English and conduct class discussions so that they develop the habit of thinking in English. Such classroom situations are necessary for students to accept, absorb new language materials, update their knowledge systems, and construct new cognitive structures. In English class teaching, creating an appropriate English learning environment and learning environment is very important for students' English acquisition. Teachers can use "exemplary teaching" or "anchor teaching" based on real examples or problems, so that students can experience and experience in real situations and complete the construction of the knowledge they have learned. Teachers should also give full play to the advantages of multimedia-assisted teaching, provide and construct a real language environment, and achieve situational teaching. Multimedia visualization, diversification, and vivid features are conducive to the multi-dimensional three-dimensional input of language teaching and make the teaching focus more prominent. These characteristics are very important for stimulating students' interest in learning and giving full play to the students' subjective initiative and the main role of learning [5]. It is also helpful to improve students' English language ability.

\section{Conclusion}

The constructivist learning theory emphasizes that learners always assimilate and absorb knowledge on the basis of the original cognitive structure, adapt and reorganize new knowledge and meaning, update their cognitive structure, and achieve new meaning construction. In college English teaching, teachers should apply the essence of constructivist learning theory to teaching according to the characteristics of the students in their own class. Students should be the main body of the teaching process, and the teacher should be the leader. And the important role of knowledge construction, to strengthen class discussion, collaboration and communication, to develop students' ability to learn independently, to further improve and perfect college English teaching based on 
constructivism theory, improve students' language output.

\section{References}

[1] Fan Lin, Zhang Qiyun. The fit of constructivist teaching theory with English teaching reform [J]. Foreign Language and Foreign Language Teaching, 2003, (04): 28-32.

[2] Jia Chunrong. The fit of constructivist teaching theory and English teaching reform [J]., 2012, (18): 165-165.

[3] Lu Jing. The fit of constructivist teaching theory and English teaching reform [J]. Jilin Province Teaching Journal of the Chinese Academy of Education, 2013, (9): 61-62.

[4] Zhang Yu. English education reform and construction of the theological teaching theory of the agreement [J]. Wind, 2015, (29).

[5] Li Yanxia. The fit between English teaching reform and constructivist teaching theory [J]. Shan HaiAfter ,2016, (2). 